\title{
Martyrdom, Literary Experiment and Church Politics in Jerome's Epistula Prima, to Innocentius, on the septies percussa
}

\author{
Steff Coppieters, Danny Praet, Annelies Bossu ${ }^{1} \&$ Maarten Taveirne ${ }^{2}$ \\ Universiteit Gent, vakgroep Wijsbegeerte en Moraalwetenschap, \\ Blandijnberg 2, Gent \\ Danny.Praet@UGent.be
}

\begin{abstract}
Jerome's Epistula prima is a remarkably hybrid text. It contains a miraculous account of the trial and failed execution of a woman from Vercelli, who is falsely accused of adultery and eventually saved from further persecution by Jerome's patron, Evagrius of Antioch. In our article we discuss the martyrological and novelistic elements of Jerome's text and analyze how he related a cruel, but trivial trial with anonymous protagonists to contemporary Church politics and gave it an ascetical undertone. Furthermore, we link these elements to the interests of Jerome's intended readership. Overall, we argue that Jerome wrote the Epistula prima not only as a hyper-rhetorical showcase to advertise himself as a Christian writer or to eulogize Evagrius, but that he included subtle yet meaningful literary and ideological references in his text.
\end{abstract}

1 The doctoral research of Annelies Bossu is financed by the Fwo (Research Foundation Flanders)-project G.0633.10N, entitled Sacred Fiction. A narratological-rhetorical analysis of novelistic topicality and generic specificity in late antique hagiography, supervised by Prof. Dr. Danny Praet and Prof. Dr. Koen De Temmerman.

2 The doctoral research of Maarten Taveirne is financed by the Fwo (Research Foundation Flanders)-project G.0620.10N, entitled Biblical Stylization of the Greek and Latin acta martyrum \& passiones of Late Antiquity (4th-6th centuries), supervised by Prof. Dr. Kristoffel Demoen, Prof. Dr. Danny Praet and Prof. Dr. Em. Marc Van Uytfanghe. 


\section{Keywords}

Jerome - Epistula prima - martyrdom - ancient novel - Church politics - asceticism septies percussa

Jerome's letter to Innocentius (ep. 1$)$ is a truly remarkable text. It is a hybrid composition, one we will analyze as a literary experiment with a curious combination of literary and ideological motifs. It is accepted by most scholars ${ }^{3}$ as his first literary work, or at least as the first work that has been preserved. ${ }^{4}$ Jerome sent off the letter in $375,{ }^{5}$ when Evagrius of Antioch ${ }^{6}$ was his patron. The intended readers were probably ascetic groups in Northern Italy ${ }^{7}$ although we may assume that it also circulated among a wider Latin Christian audience. Andrew Cain has recently questioned the scholarly communis opinio that Jerome published the letter in $382,{ }^{8}$ as part of the collection to which he gave

3 But see Schwind Johannes, "Hieronymus' Epistula ad Innocentium (epist. 1) - ein Jugendwerk?", Wiener Studien 110 (1997) 171-186 who rejects the standard date of 374-375 (based upon Jerome's and Evagrius' years in Northern Italy, the death of Innocentius in 375 as a terminus ante quem, etc.) and also rejects stylistic arguments (the so-called youthful exuberance) as a possible support for an early date. We accept the traditional date of the letter and will situate it in its contemporary context.

4 Some scholars take the commentary on Obadiah to be his first work, see Booth Alan, "The Date of Jerome's Birth," Phoenix 334 (1979) 351 and Rebenich Stefan, Hieronymus und sein Kreis. Prosopographische und sozialgeschichtliche Untersuchungen (Stuttgart: Franz Steiner Verlag, 1992) 29.

5 Although the primary addressee was Innocentius, we can safely assume that Jerome wrote his text for a broader readership, given the literary qualities of the letter. It is however also possible that another, more modest version was sent to Innocentius and that this text was afterwards embellished by Jerome for a wider readership. Cf. in general on these issues Michael Trapp's introductory chapter "What is a Letter?" in his Greek and Latin Letters: An Anthology with Translation (Cambridge: Cambridge University Press, 2003) 3.

6 See for his patronage Rebenich, Hieronymus 52-75.

7 The letter was dedicated to Innocentius who was active within such groups, as was Evagrius, and also the setting of the narrative seems to suggest a North-Italian ascetic public.

8 Andrew Cain recently denied this, because it is never found in letter-clusters in manuscripts that are linked to the collection Epistularum ad diuersos liber, see Cain Andrew, The Letters of Jerome. Asceticism, Biblical Exegesis, and the Construction of Christian authority in Late Antiquity (Oxford: Oxford University Press, 2009) 14-15. Cain attempted to reconstruct the liber by combining clusters he has found in different manuscripts, but there is not a single manuscript that contains the entire collection he sees as the liber. So we would argue that his exclusion of ep. 1 is actually based upon an argumentum e silentio. However, this issue 
the title Epistularum ad diuersos liber. However, this issue remains beyond the scope of the present discussion. ${ }^{9}$

Due to its rhetorical pathos and its early date scholars have disregarded this text for its declamatory nature ${ }^{10}$ and they appreciated it merely as Jerome's first literary product designed to promote his talents as a Christian writer. The main narrative focuses on a woman who is wrongly accused of adultery, tortured and condemned, although the executioners fail seven times to put her to death. These failed attempts inspired medieval scribes to refer to this woman and to the letter as septies percussa. At the end of the letter Jerome turns to his patron Evagrius of Antioch. He first includes some brief and tantalizing references to contemporary Church politics in Milan and Rome, and then reveals that Evagrius also intervened with the emperor to obtain justice for this falsely accused woman. We will try to understand why Jerome linked a fairly trivial adultery case, described at length in a sensationalistic style, with the more important religious and political struggles, to which he alludes in a single sentence at the end of the letter.

Jerome inserted a rhetorical declamation, or a short story with novelistic elements, or a profane passio, or, according to Fontaine, a fairy tale in the style of Apuleius, ${ }^{11}$ into a letter which has also a Church political message. The way in which Jerome narrated this adultery case combines, as we will show, elements from martyrology, the novel, sexual morals and Church politics. All these elements make this text a very interesting literary document.

\section{Martyrdom, Novelistic Topoi and Church Politics in Epistula Prima}

After a prologue (ep. 1, 1-2), in which Jerome uses the humility topos to declare himself incapable of describing the miracle that will follow (de eius miraculo rei, quae in nostram aetatem inciderat ep. 1,1$),{ }^{12}$ he begins his story in medias

remains beyond the scope of the present discussion as the themes were already present when Jerome wrote the letter in 375 .

9 See Nautin Pierre, "La liste des oeuvres de Jérôme dans les De Viris Illustribus," Orpheus (1984) 319-334. Jerome uses this title in De Viris illustribus §135.

10 Jacques Fontaine called it "une déclamation bien enlevée, dédiée à Évagre, dont le panégyrique sert de peroraison. Nil plus," in : "L'esthétique littéraire de la prose de Jérôme jusqu'à son second départ en Orient," in Duval Yves-Marie (ed.), Jérôme entre l'Occident et l'Orient. $X V I^{e}$ centenaire du départ de saint Jérôme de Rome et de son installation à Bethléem. Actes du colloque de Chantilly (septembre 1986) (Paris: Les études augustiniennes, 1988) 328.

11 Fontaine, "esthétique" 327.

12 The Latin text of ep. 1: Hilberg Isidorus, Sancti Eusebii Hieronymi Epistulae CsEL 54 I (Vindobonae: Tempsky 1910/1996). We will use the English translation by Rebenich Stefan, 
res. The setting is rather grim: the North-Italian town of Vercellae (Vercelli in Piemonte), described by Jerome as a ghost town almost in ruins: Igitur Uercellae Ligurum ciuitas haud procul a radicibus Alpium sita, olim potens, nunc raro habitatore semiruta $($ ep. 1,3$) \cdot{ }^{13}$

Semiruta ("half in ruins") and raro habitatore ("nearly depopulated") refer to Lucan, Pharsalia 1, 24-2 $7^{14}$ where the poet describes the ruins of Italy during the Civil War between Caesar and Pompey. This has been interpreted in different ways, ${ }^{15}$ but has also been seen as an allusion to the "civil war" between Arians and orthodox Christians. ${ }^{16}$ This suggestion seems the most interesting, as the famous bishop of Vercelli, Eusebius, who is curiously absent from this text (he might have been dead by the time of the trial), ${ }^{17}$ was a Nicene "hero" in the battle against Arianism. He was banished to the East and, upon his return, imposed an ascetic lifestyle on his clergy. ${ }^{18}$ The Arians were far from defeated in

Jerome (London: Routledge 2002) 63-69. The quoted phrase is translated as: about the miraculous event that has happened in our time (Rebenich, Jerome 63).

13 Vercellae, then, is a Ligurian town, situated not far from the foot of the Alps, once important, but now sparsely populated and lying half in ruins (Rebenich, Jerome 64).

14 At nunc semirutis pendent quod moenia tectis / Urbibus Italiae lapsisque ingentia muris / Saxa iacent, nulloque domus custode tenentur / Rarus et antiquis habitator in urbibus errat. (But now the walls are tumbling in the towns of Italy,/ the houses half-destroyed, and, the defences collapsed,/ the huge stones lie; no guardian occupies the homes/ and in the ancient cities wanders only an occasional inhabitant. Translation by Braund Susan H., Lucan. Civil War (Oxford: Oxford University Press, 2008) 3). See Godel Robert, "Réminiscences des poètes profanes dans les lettres de Saint Jérôme," Museum Helveticum 21 (1964) 68, confirmed by Hagendahl Harald, "Jerome and the Latin Classics," Vigiliae Christianae 28 (1974) 220, but without relating the reference to the content or context of the letter. It is however true that not every classical reference in this letter bears relevance to the content.

15 Scholars have looked for several interpretations, ranging from seeing the fragment as evidence for the decline of cities to ascribing it to the fact that in a garrison town like Vercelli the population had become a mix between Romans and barbarians, to Jerome's and his elite readers' dislike, see Brogiolo Gian Pietro, "Ideas of the Town in Italy during the Transition from Antiquity to the Middle Ages," in: Gian Pietro Brogiolo \& Bryan WardPerkins (eds.), The Idea and Ideal of the Town between Late Antiquity and the Early Middle Ages (Leiden: Brill, 1999) 102-103.

16 Cracco Ruggini Lellia, "La città nel mondo antico. Realtà e idea," in: Gerhard Wirth (ed.), Romanitas - Christianitas: Untersuchungen zur Geschichte und Literatur der römischen Kaiserzeit. Johannes Straub zum 70. Geburtstag am 18. Oktober 1982 gewidmet (Berlin: De Gruyter, 1982) 64-65.

17 Hagith Sivan, "Le corps d'une pécheresse, le prix de la piété: la politique de l'adultère dans l'Antiquité tardive," Annales. Histoire, Sciences Sociales 2 (1998) 233 n.8.

18 Rousseau Philip, Ascetics, Authority and the Church in the Age of Jerome and Cassian (Oxford: Oxford University Press, 1978/2010) 87. 
the West, so the negative image of Vercelli with its references to civil war might direct discerning readers' attention to internal Christian controversies. As an afterthought, one of the messages of the story of an innocently condemned woman, eventually rescued by a pro-Nicene activist, Evagrius of Antioch, could have been that justice and orthodoxy are represented by one and the same party: the pro-Nicene.

Within this grim setting a trial is staged. No context is provided: the protagonists remain anonymous and their social rank is not made explicit. Jerome briefly resumes the case: a husband has accused his wife and her alleged young lover of adulterium (ep. 1, 3). The case is brought to the consularis who wants to extract a confession from the young man by torturing him:

Neque multo post, cum liuidas carnes ungula cruenta pulsaret et sulcatis lateribus dolor quaereret ueritatem, infelicissimus iuuenis uolens conpendio mortis longos uitare cruciatus, dum in suum mentitur sanguinem, accusauit alienum solusque omnium miser merito uisus est percuti, quia non reliquit innoxiae, unde posset negare $($ ep. 1,3$){ }^{19}$

The young man, accused of having been the woman's lover, appears as a coward, who prefers death over torture, and is said to have deserved execution. From this we can deduce that Jerome did not intend to write a social critique of the contemporary justiciary system. This depiction of the male character contrasts sharply with the woman's, who is clearly favored by the narrator.

at uero mulier sexu fortior suo, cum eculeus corpus extenderet et sordidas paedore carceris manus post tergum uincula cohiberent, oculis, quos tantum tortor alligare non poterat, suspexit ad caelum et uolutis per ora lacrimis: "tu," inquit, "testis, domine Iesu, cui occultum nihil est, qui es scrutator renis et cordis, non ideo me negare uelle, ne peream, sed ideo mentiri nolle, ne peccem. at tu, miserrime homo, si interire festinas, cur duos interimis innocentes? equidem et ips a cupio mori, cupio inuisum hoc corpus exuere, sed non quasi adultera. praesto iugulum, micantem intrepida excipio

19 Shortly afterwards, excruciating tortures were inflicted to discover the truth. When the blood-stained hook struck the young man's livid flesh and tore furrows in his side, the unhappy youth sought to avoid prolonged pain by a speedy death, and giving a false account of his own passions, he involved another in the charge. Thus it appeared that he was of all men the most miserable and that his execution was just for he left to an innocent woman no chance of self-defence (Rebenich, Jerome 64). 
mucronem, innocentiam tantum mecum feram. non moritur, quisquis uicturus occiditur" (ep. 1, 3). ${ }^{20}$

The gendered characterization in terms of weak men versus strong women is a typical technique of ancient novelistic literature, ${ }^{21}$ both pagan and Christian. Throughout the narrative, the Vercellan woman is contrasted with male characters to whom she is superior. The phrase sexu fortiori suo continues the novelistic gendered characterization. The young man's weakness is even more stressed, as the woman echoes the narrator's previous infelicissimus iuuenis by addressing him as miserrime homo, a more damning epithet. She presents herself as "fearless" in the face of death by the sword. Her courage is to be contrasted with the young man's acceptation of death to escape further torture. This contrast between moral strength and the lack thereof also points to the martyrological undertone of the woman's trial and execution that is emerging in the text. ${ }^{22}$

20 But the woman was more couragous than her sex. Although her body was stretched upon the rack, and although her hands, stained with the filth of the prison, were tied behind her, she looked up to heaven with her eyes, which alone the torturer had been unable to bind, and while the tears rolled down her face, cried: "You are my witness, Lord Jesus, to whom nothing is hidden, who tries the reins and the heart. You are my witness that it is not to save myself from death that I make the denial, but that it is to save myself from sin that I am unwilling to lie. And as for you, unhappy man, if you are hastening to perish, why must you destroy two innocent persons? I also, myself, desire to die, desire to put off this hated body, but not as an adulteress. I offer my throat, I welcome the gleaming sword without fear, so long as I take my innocence with me. He does not perish, who is triumphant in his death" (Rebenich, Jerome 64-65 but for the last line another possible translation is: He does not perish who is killed in order to live again, see below).

21 In scholarship on the ancient Greek novel, the thesis of the strong, resourceful and persuasive heroine, in sharp contrast to the passive and weak hero, has become a topos, cf. Haynes Katharine, Fashioning the Feminine in the Greek Novel (London: Routledge, 2003) especially 81-10o, for the weak heroes, with references to more literature on the subject. For the interpretation of the passivity of the novelistic heroes in terms of equivalence of the male and female roles, cf. Konstan David, Sexual Symmetry. Love in the Ancient Novel and Related Genres (Princeton: Princeton University Press, 1994) especially 14-98. See Shaw Brent, "Body/Power/Identity: Passions of the Martyrs," Journal of Early Christian Studies 43 (1996) 272, on the parallel between the woman in Jerome's letter and Leucippe in Achilles Tatius, Leucippe and Clitophon, VI, 18-22.

22 There is a complex nexus between martyr texts and ancient Greco-Roman fiction, as several themes, motifs, scenes and characterization techniques are found in both martyr literature and ancient fiction. Some examples that are present in ep. 1: Chariclea is to be executed innocently (Heliodorus, Aethiopica, VIII.9.7); invoking divine powers as 
In the first sentence of her direct speech, the woman defies the judge and the executioner by addressing to Jesus a message she might want her persecutors to believe (i.e. that she was innocent), as one would normally expect. Her words characterize her as a Christian martyr.

The text has been called a "profane martyr act," ${ }^{23}$ and some elements clearly point in that direction: Hildegund Müller has listed several topoi of martyrological literature in ep. 1, such as the woman's constancy, the way she invokes God as her witness, the focus on her eyes looking up to heaven during torture (ep. 1, 3, and 4 see below), the way the judge becomes more cruel because of the woman's courageous attitude (ep. 1, 4-5 see below), and the executioner's failures (ep. 1, 7-11 see below). ${ }^{24}$

It is however important to underline the paradoxical nature of this "martyrdom." First, when she exclaims cupio inuisum hoc corpus exuere she echoes the readiness to die as expressed by several martyrs, but she does so in an ambiguous way: it is hard for the reader to decide whether she hates her body as a result of the torture or as a dualistic rejection of the material body. The whole letter is an example of the subtle propaganda for asceticism by use of martyrological themes. Secondly, it lies in the nature of the trial ${ }^{25}$ and especially the quaestio procedure that denial and confession are at stake, but we believe it

witnesses to one's innocence (Heliodorus, Aethiopica, VIII.9.12), public sympathy with the condemned (Heliodorus, Aethiopica, VIII.9.13). The obvious parallel, Achilles Tatius Leucippe and Clitophon, VI, 18-22, is referred to in $\mathrm{n} .21$ above.

Berschin Walter, Biographie und Epochenstil im lateinischen Mittelalter. Vol. 1: von der Passio Perpetuae zu den Dialogi Gregors des Grossen (Stuttgart: Anton Hiersemann Verlag, 1988) 134.

24 Müller Hildegund, "Der älteste Brief des heiligen Hieronymus. $\mathrm{Zu}$ einem aktuellen Datierungsvorschlag," Wiener Studien 111 (1998) 208-9 - this article is a reply to Schwind's argument (see n. 3) to date the letter to Jerome's stay in Bethlehem (after 386).

The juridical and historical circumstances of the trial in Vercelli in relation to the history of torture and morality in Late Antiquity are fully explored by Sivan, "corps" 231-253. With Sivan we can refer to the harsh trials that involved torture of members of the elite in Rome and Northern Italy under Valentinian I, attested by Ammianus Marcellinus, Res Gestae, 28, 1 (discussed by Sivan, "corps" 238). Ammianus states that the emperor, out of moralism, blurred the distinctions between treason and lesser crimes (such as magic for private purposes, adultery and other sexual offences, see n. 46 on aristocratic women convicted for adulterium and stuprum in Ammianus Marcellinus), meaning that torture could be applied, even to the elite, whenever it was required: ut erat uitiorum inimicus acer magis quam seuerus, uno proloquio in huius modi causas, quas adroganter proposito maiestatis inminutae miscebat, omnes quos iuris prisci iustitia diuorumque arbitria quaestionibus exemere cruentis, si postulasset negotium, statuit tormentis adfligi (Res Gestae, 28, 1, 11), see den Boeft Jan, Drijvers Jan Willem, Den Hengst Daan \& Teitler Hans C., 
is also possible to interpret this as an inversion of the classical martyrological discourse: the young woman is a "denying" instead of a "confessing" martyr. Jerome inverts the old martyrological paradox as e.g. expressed by Tertullian in Apologeticum 1, 10-12 that, unlike common criminals, Christians never deny the accusation of being a Christian. ${ }^{26}$

In Jerome's letter, the accused woman's goal is the same as the martyr's: she wants to keep up her purity, but she achieves this by doing the opposite of what a martyr is supposed to do during his or her trial: negare. This inversion of the classical martyrdom paradox points out the shift from a classical, religious to a profane martyr act experiment. Moreover it is an extra element in the shift from a Christianity focusing on faith to a Christianity focusing on the body. In the paragraphs of the letter that follow the words of the woman cited above, Jerome plays with the confiteri-negare-opposition: the alleged lover's confession is contrasted with the women's persistent denial as expressed, first by the narrator $(e p .1,5)$ and then also by the governor $(e p .1,6) .{ }^{27}$

Philological and Historical Commentary on Ammianus Marcellinus XXVII (Leiden: Brill, 2011) 27-29.

26 Omne malum aut timore aut pudore natura perfudit. Denique malefici gestiunt latere, deuitant apparere, trepidant deprehensi, negant accusati, ne torti quidem facile aut semper confitentur, certe damnati maerent. Dinumerant in semetipsos mentis malae impetus, uel fato uel astris imputant; nolunt enim suum esse, quod malum agnoscunt. Christianus uero quid simile? Neminem pudet, neminem paenitet, nisi plane retro non fuisse. Si denotatur, gloriatur; si accusatur, non defendit; interrogatus uel ultro confitetur, damnatus gratias agit. Nature steeps every evil thing with either fear or shame. Why, evil-doers are eager to escape notice; they avoid appearing; they are anxious when caught; they deny when accused; even under torture they do not easily or always confess; at all events, when condemned they lament. They tell how often they have felt the impulses of a mind distraught; they set their deeds down to fate or to the stars; they will not admit to be their own what they recognize as evil. But look at the Christians! There you have quite another story; not a man of them is ashamed of it, not a man regrets - unless, indeed, that he was not a Christian earlier. If he is denounced [as a Christian], he glories in it; if he is accused, he does not defend himself; when he is questioned, he confesses without any pressure; when he is condemned, he renders thanks (translation by Terrot R. Glover in: Terrot R. Glover \& Gerald H. Rendall, Tertullian: Apology. De Spectaculis. Minucius Felix: Octavius. Loeb Classical library 250 (London: Heinemann 1953) 7-9).

27 See: illa pro confitente negat (ep. 1, 5: She, for the confessor's sake, denies it (Rebenich, Jerome 66) and esse credibilius reor noxiam ream negare de scelere, quam innocentem iuuenem confiteri (ep. 1, 6, said by the governor: I think it more credible that a guilty woman should deny a crime than that an innocent young man should confess one (Rebenich, Jerome 66)). 
A second set of connecting themes is introduced in the accused woman's words: death and innocence, that is, the violent death of the innocent. Several instances of this cluster will appear throughout the narrative, even ironically applied to the executioner. ${ }^{28}$ Furthermore, this theme is developed by Jerome as a means to highlight Evagrius' support of the innocent. The importance of this aspect of the text could have led Jerome to address the letter to his friend with the "ominous" name of "Innocentius" and this has even been used to argue for the letter's fictional nature. ${ }^{29}$ Later on in this paper, we will argue that Jerome could have had other, hagiographical reasons to choose this friend, who conveniently happened to have a telling name. As with the negare theme, the narrator underlines the woman's innocence right before we hear the very first words she utters. ${ }^{30}$ In this way Jerome adds extra fuel to the suggestion that the young man is somehow "guilty," not of the charge of adultery, but where truth and justice are concerned: he lied when he was tortured and his lies caused injustice to the woman, as she could not credibly deny the accusations anymore.

The young woman's speech contains not only the central themes of the rest of the story, but the phrase non moritur, quisquis uicturus occiditur also points forward to the actual outcome: the executioners will try to kill her in vain and after the seventh attempt she will be only seemingly dead. The most obvious solution for uicturus is to construe it from uiuere, as it stands between moritur and occiditur. Stefan Rebenich noticed that uincere "to overcome" is a valid candidate as well. ${ }^{31}$ Moreover, this befits the martyrological atmosphere of the story, since the association between victory and a martyr's death is well known in Christian literature. ${ }^{32}$

28 In paragraphs 10 and 11 (see below).

29 Schwind, "Hieronymus" 180.

$30 \quad$ Innoxiae in ep. 1, 3 .

31 Rebenich, Jerome 176-177 n. 23 .

32 For evidence for the "Latin" tradition, juxtaposing uincere - occidere see Tertullian, Apologeticum 50, 2-3 Uictoria est autem, pro quo certaueris, obtinere. Ea uictoria habet et gloriam placendideo et praedamuiuendiinaeternum. Sedobducimur. Certe, cumobtinuimus. Ergo uicimus, cum occidimur, denique euadimus, cum obducimur. Licet nunc sarmenticios et semaxios appelletis, quia ad stipitem dimidii axis reuincti sarmentorum ambitu exurimur, hic est habitus uictoriae nostrae, haec palmata uestis, tali curru triumphamus; Cyprian, ep. 59,17,1: Sacerdos dei euangelium tenens et Christi praecepta custodiens occidi potest, non potest uinci. In later martyr's passiones this theme frequently recurs, e.g. Passio Caeciliae (BHL 1495): Denique putabat se tunc hostis sanctos Dei occidendo uincere, illi autem melius occisi uincebant. Interrogati ilico confitebantur, damnati gratias referebant (And then the devil supposed that he might overcome the saints of God, his enemy, by slaughtering 
Next, the effect of the woman's words on the judge is the same as of a classical martyr: she outrages him by her defying attitude:

Igitur consularis pastis cruore luminibus ut fera, quae gustatum semel sanguinem semper sitit, duplicari tormenta iubet et saeuum dentibus frendens similem carnifici minitatus est poenam, nisi confiteretur sexus infirmior, quod non potuerat robur uirile reticere $(e p .1,4) \cdot{ }^{33}$

The judge is the stock character we find in (later, i.e. post-Nicene) passions of the martyrs: he quickly loses his temper when the woman refuses to give in and is dehumanized by the narrator as a bloodthirsty wild beast. His threats against the executioner prove to the reader how stubbornly ignorant the judge is of the woman's strength and innocence. His (antique) common sense gender assumptions about the female sexus infirmior versus the robur uirile are explicitly subverted by the narrator and the woman. In this way he and the executioner are ironically members of the "weaker sex," as well as the alleged lover. This novelistic theme is interwoven with a rewording of the martyrological opposition between confiteri and negare (here expressed as reticere, although not a synonym).

The topos of the martyr who is unmoved by torture is further developed in the explicit description of the torture scene that follows:

Succurre, domine Iesu: ad unum hominem tuum quam plura sunt inuenta supplicia! crines ligantur ad stipitem et toto corpore ad eculeum fortius alligato uicinus pedibus ignis adponitur, utrumque latus carnifex fodit nec papillis dantur indutiae: inmota mulier manet et a dolore corporis spiritu separato, dum conscientiae bono fruitur. uetuit circa se saeuire tormenta $($ ep. 1,5$) \cdot{ }^{34}$

them, but those slaughtered more fittingly prevailed. §1, ed.-tr. by Upchurch Robert, Elfric's Life of the Virgin Spouses (Exeter: University of Exeter Press 2007) 172), see also Passio Symphorosae \& VII filiorum (BHL 7971) §2, Passio Felicitatis \& VII filiorum (BHL 2853) §1; Passio Caloceri \& Parthenii (B HL 1534) §1.

33 The governor, who had been feasting his eyes upon the bloody spectacle, now, like a wild animal that after once tasting blood always thirsts for it, ordered her torture to be doubled, and cruelly gnashing his teeth, threatened the executioner with like punishment if he failed to extort from the weaker sex a confession which manly strength had not been able to keep back (Rebenich, Jerome 65).

34 Help, Lord Jesus. How many tortures have been invented for this one creature of yours! Her hair is bound to a stake, her whole body is fixed more firmly on the rack, and fire is put to her feet. The executioner jabs her on both sides, and even her breasts are not spared. 
The violent torture and the woman's perseverance in this passage have been important in recent scholarship for the interpretation of the text as a rhetorically overblown adaptation of martyrological literature. The gruesome and explicit description of inflicted bodies is no exception in Jerome's oeuvre. Later on in his literary career he wrote a number of vitae, clearly with the double aim of creating a Christian literature that could appeal to high-brow intellectuals ${ }^{35}$ and of presenting ascetics as the heirs to the bloody martyrs. ${ }^{36}$ In the introduction to the Vita Pauli (dated ca. 375-380), ${ }^{37}$ Jerome linked the martyrium sine cruor $e^{38}$ of the first hermit to the age of the persecutions. In the vita he included two very short accounts of anonymous martyrs: one, of a man who was covered in honey and exposed to mosquitoes (Perseuerantem in fide martyrem et

Still the woman remains unshaken, and her spirit is free from the pain of her body; still enjoying a clear conscience she refuses to allow the tortures to vent their rage upon her (Rebenich, Jerome 65).

35 See Coleiro E., “St. Jerome's Lives of the Hermits," Vigiliae Christianae 11 (1957) 161-178; Fuhrmann Manfred, "Die Mönchsgeschichten des Hieronymus: Formexperimente in erzählender Literatur," in: Manfred Fuhrmann (ed.), Christianisme et formes littéraires de l'antiquité tardive en Occident. Huit exposés suivis de discussions (Genève: Fondation Hardt 1977) 41-89; Kech Herbert, Hagiographie als christliche Unterhaltungsliteratur. Studien zum Phänomen des Erbaulichen anhand der Mönchsviten des hl. Hieronymus (Göppingen:

A. Kümmerle 1977).

36 Especially the Vita Pauli (and the Vita Malchi, as will be illustrated below), see Rebenich Stefan, "Inventing an Ascetic Hero. Jerome's Life of Paul the First Hermit" in: Andrew Cain \& Josef Lössl (eds.), Jerome of Stridon. His Life, Writings and Legacy (Farnham: Ashgate, 2009) 26. In the Vita Hilarionis this theme seems less present, but one should note that Jerome expected that his readers were familiar with his previous Vitae (cf. Vita Hilarionis, prologue) and subsequently read it with the previous Lives in mind.

37 For Jerome's vitae we refer to Leclerc Pierre, Morales Edgardo Martín \& De Vogüé Adalbert, Jérôme. Trois vies de moines (Paulus, Malchus, Hilarion). Introduction par Pierre Leclerc, Edgardo M. Morales, Adalbert Vogüé. Texte critique par Edgardo M. Morales. Traduction par Pierre Leclerc. SC 508 (Paris: Du Cerf, 2007). The editors adopt a more precise date for the Vita Pauli: 376 (Introduction, page 15). Stefan Rebenich dates it to the mid-37os during Jerome's stay in Chalcis or shortly after his return from the desert to Antioch and before he went to Constantinople (Rebenich, "Inventing an Ascetic Hero" 17).

38 The expression is taken from Sulpicius Seuerus, Vita Martini ep. 2, 12, although Jerome had formulated the same idea in the Vita Malchi, $§ 6,5$. See also Jerome's sermon, addressed to his monks in Bethlehem, De persecutione christianorum, 16-17 (CCSL 78 pars II, ed. Morin, 402): Non putemus tantum in effusione sanguinis esse martyrium: semper martyrium est. Adulescentem libido persequitur: uult libido effundere sanguinem animae (We should not believe that martyrdom merely consists in bloodshed: there is always martyrdom. [For example], a young man is "persecuted" by lust: that is, lust wants to shed the blood of his soul. Our translation). See also n. 42. 
inter eculeum laminasque uictorem, iussit melle perungi et sub ardentissimo sole religatis post tergum manibus reponi, scilicet ut muscarum aculeis cederet qui ignitas sartagines ante superasset. Vita Pauli $\S 3,1),{ }^{39}$ the second (Vita Pauli §3, 2-4) of a martyr who quite famously withstood every type of traditional torture and was then exposed to erotic persuasion. Jerome seems to have derived some pleasure from the description of a locus amoenus (with roses and lilies to symbolize martyrdom and virginity) in which the martyr was tied down to a soft bed with garlands. Jerome presents to the reader a beautiful prostitute who coepit... quod dictu quoque scelus est, manibus adtrectare uirilia (Vita Pauli, §3, 3), which was piously translated in the Nicene Fathers Series as "wicked even to relate! to handle his person." ${ }^{40}$ The man decided to overcome pleasure with pain by biting off his own tongue. In the Vita Malchi too, Jerome combined reflections about martyrdom and asceticism (Habet et pudicitia seruata martyrium suum. Vita Malchi, §6, 5), ${ }^{41}$ and introduced elements from novelistic literature into hagiography. The letter on the septies percussa was written a few years before the Vita Pauli but already displays a comparable mixture of martyrdom, asceticism, eroticizing voyeurism, propaganda and entertainment. ${ }^{42}$

39 When one martyr, remaining steadfast in faith, refused to give in amidst racks and red-hot metal plates, the order was given for him to be smeared with honey and placed beneath the blazing sun, with his hands tied behind his back, so that he who had earlier survived the burning metal plates might succumb to the mosquitoes (translation by Carolinne White Early Christian Lives. Penguin Classics (London: Penguin 1998) 76).

Translation by William Henry Fremantle in St. Jerome: Letters and Select Works. Nicene and Post-Nicene Fathers ser. 2 vol. 6 (Peabody (Mass.): Hendrikson, 1892 repr. 1994) 299. Carolinne White (ibid., see n. 39) translates it as: to touch his private parts with her hands. Chastity preserved has its own martyrdom, too (tr. White, Early Christian Lives 125). These words are said by the monk Malchus to his "fiancée" when he wishes to kill himself to avoid the loss of virginity as he is forced by his kidnappers to marry a female fellow captive. Eventually when his "fiancée" also wishes to remain chaste, the couple decides not to commit suicide and agrees on a marriage in name only - the woman would become Malchus' coniugem pudicitiae (Vita Malchi §6, 7). Edgardo Morales and Pierre Leclerc refer in n. 1 on page 198 of their edition to ep. 1 and to the "Widow of Ephesus" in Petronius (see n. 62). Jerome puts the same catchphrase in the mouth of the virgin Demetrias (ep. 133, 5).

42 For the link between martyrdom and asceticism in Jerome, see Recchia Vincenzo, "Verginità e martirio nei colores di S. Gerolamo," Vetera Christianorum (1966) 45-68; see also Jerome's sermon De persecutione christianorum (see n. 38) on which see Jay Pierre, «La référence au martyre dans les homélies de Jérôme. » in: Louis Holtz, Jean-Claude Fredouille, Marie-Hélène Jullien (eds.), De Tertullien Aux Mozarabes : Mélanges offerts à Jacques Fontaine, membre de l'Institut, à l'occasion de son $70^{e}$ anniversaire par ses élèves, amis et collègues, I (Paris: Institut d'Études Augustiniennes, 1992) 157-166. One should also 
These martyr accounts signal both the continuity of Jerome's literary career and the ascetic radicalization he underwent between Epistula prima and the Vita Pauli. Brent Shaw wrote that this letter "is cast in that rhetorical mixture of eroticism and outright pornography of which Jerome, a saint, was particularly capable." 43 The pornographic nature of the torture by pleasure and prostitute in the Vita Pauli is clear, but it is perhaps exaggerated to put the torture scene in the septies percussa on the same level and to put "erotic" on a par with "pornographic". The two scenes differ in three aspects. Firstly, in the Vita Pauli the goal of the torture is clearly to convert the martyr away from an ascetic life which, by the way, allows Jerome to suggest an identity-relation between asceticism and "true" Christianity. In the septies percussa the woman is married and will only move to a uillula inhabited by virgins after the whole ordeal, and this on the initiative of the clerics. ${ }^{44}$ Secondly, in the Vita Pauli the antagonist is a professional in providing "a happy ending," in the Epistula prima the woman faces a professional in life-ending, although we should add that neither was professionally successful in Jerome's narratives. The third aspect is that the Vita Pauli focuses on the genitalia of the male martyr, whereas in the case of the septies percussa only secondary sexual features, her breasts, are exposed. In

refer to Jerome's famous dream in $e p .22,30$, where he depicts himself as a martyr on trial, accused of being a ciceronianus instead of a christianus, see Shaw Brent, "Judicial Nightmares and Christian Memory." Journal of Early Christian Studies 114 (2003) 533-563. More generally, the link between asceticism or monasticism and martyrdom is discussed by Malone Edward E., The Monk and the Martyr. The Monk as the Successor of the Martyr. (Diss.) (Washington, 1950); Viller Marcel, "Le martyre et l'ascèse." Revue d'ascétique et de mystique 6 (1925) 105-149.

43 Shaw Brent, "Body/Power/Identity" 269-312, 272-274 are on Jerome's ep. 1, page 272 is quoted.

44 Virginia Burrus follows Brent Shaw (see n. 43 above) and sees sexual innuendos in the description of the torture and execution. However, she links the woman's martyrdom to asceticism not in the way we do: "A second soldier must be summoned before the woman can be killed - but it appears that he succeeds only because she now desires death. Indeed, here as in other ancient Christian accounts of torture and resistance, the plot pivots on the subject's consent: the perverse extravagancy of her passivity is the source of her power. Martyrdom is thereby construed as an ascetic practice [...]." (Burrus Virginia, The Sex Lives of the Saints. An Erotics of Ancient Hagiography (Philadelphia: University of Pennsylvania Press, 2011) 55). We point out that the woman expresses her desire to die already when she was tortured $(e p .1,3)$ and that the woman's asceticism as we see it in this letter is far from "empowering" as it was the clergy who brought her to the virgins (she did not take the initiative). See also in general on the empowerment of suffering martyrs, Perkins Judith, The Suffering Self: Pain and Narrative Representation in the Early Christian Era (London and New York: Routledge, 1995) 104-123. 
this third aspect the Vita Pauli is pornographic even in the modern legal definition of the word. But one could argue that the Epistula prima has an erotic undertone. In ancient society, the erotic impact of breasts ran parallel to the social status of the woman whose breasts were object of the gaze. Although the letter never explicitly identifies the woman or her husband as members of the elite, the whole court procedure ${ }^{45}$ and the intervention of high Church officials point in this direction. So the exposure of the breasts of this particular woman would have been seen as sexually degrading by an ancient audience. ${ }^{46}$ Although the prime objective of publicly showing her breasts was probably to shame her, the effect on the public in the text and on the readers of the letter might have been erotic and voyeuristic, perhaps less in a sensual than in a sensationalistic way. The context of adultery and the parallel torture of her alleged lover all contribute to this erotic atmosphere. Finally, there are many examples of Jerome's taste for salacious descriptions. ${ }^{47}$ In the next paragraph the first part of the narrative comes to a climax:

45 Adulterium lawsuits did not apply to the lower classes, Codex Theodosianus 9, 7, 1: adultery charges against women from the lower classes such as barmaids were invalid, "for from those women to whom the law applies, chastity could be expected; but those girls are free from the severity of legal process whose worthless life puts them beneath observance of the law." (quum ab his feminis pudicitiae ratio requiratur, quae iuris nexibus detinentur, hae autem immunes a iudiciaria seueritate praestentur, quas uilitas uitae dignas legum obseruatione non credidit.) Translated and discussed in Brown Peter, The Body and Society. Men, Women, \& Sexual Renunciation in Early Christianity. Twentieth-Anniversary Edition with a New Introduction (New York: University of Columbia Press, 1988/2008) 24.

46 That in (late) antiquity the value of a naked body was dependent on social status can be illustrated with a reference to Ammianus Marcellinus, Res Gestae, 28, 1, 28: the executioner of two aristocratic adulteresses is burnt alive because he took away one of his victim's clothes and exposed her private parts to the public, cf. den Boeft, Jan; Drijvers, Jan Willem; Den Hengst, Daan \& Teitler, Hans C., Philological and Historical Commentary on Ammianus Marcellinus XXVII (Leiden: Brill, 2011) 63, who refer to Perpetua and Agnes covering their naked bodies during their execution. In $n$. 25 we discussed the trials in Ammianus Marcellinus, Res Gestae, 28, 1 in relation to the trial in Jerome's letter.

The most notorious example can be found in his letter De uirginitate seruanda to the young virgin Eustochium (ep. 22) where he described the sexual phantasies he experienced during his stay in the Syrian desert (putaui me Romanis interesse deliciis [...] saepe choris intereram puellarum ep. 22, 7: how often did I fancy myself surrounded by the pleasures of Rome! [...] I often found myself surrounded by bands of dancing girls). In the same letter he described Eustochium's spiritual marriage with Christ in explicitly erotic terms (Semper te cubiculi secreta custodiant, semper tecum sponsus ludat intrinsecus [...] cum te somnus oppresserit, ueniet post parietem et mittet manum suam per foramen et tanget uentrem tuum, et tremefacta consurges et dices: uulnerata caritatis ego sum. ep. 22, 
Una interim uox: "caede, ure, lacera; non feci. si dictis tollitur fides, ueniet dies, quae hoc crimen diligenter excutiat; habebo iudicem meum." iam lassus tortor suspirabat in gemitum nec erat nouo uulneri locus, iam uicta saeuitia corpus, quod laniarat, horrebat: extemplo ira excitus consularis: "quid miramini," inquit, "circumstantes, si torqueri mauult mulier, quam perire? adulterium certe sine duobus committi non potest et esse credibilius reor noxiam ream negare de scelere, quam innocentem iuuenem confiteri" $\left(\right.$ ep. 1, 6). ${ }^{48}$

The woman as a true martyr challenges the judge and her previous implicit rejection of the governor's juridical authority in favor of Christ as a supreme judge, becomes now explicit. Again the readers see how the governor is completely ignorant. Unwittingly, he claims to provide the key to explain the woman's endurance without assuming that she simply could have been innocent. Once again, this irony is stressed by the use of negare and confiteri.

The governor condemns both the young man and the woman to death: the young man's confession is deemed sufficient to prove her guilt. Amid great public interest the execution takes place outside the city walls (ep. 1, 7). The young man is beheaded, but the execution of the woman is a failure. The execution itself is another occasion for Jerome to contrast the woman's strength with the male executioners' weakness. When he tries to execute the woman, the executioner is soon exhausted and frustrated as he is not able to simply decapitate her $(e p .1,7)$ :

25: Let the seclusion of your own chamber ever guard you; ever let the Bridegroom sport with you within. [...] When sleep falls on you, He will come behind the wall and will put His hand through the hole in the door and will touch your belly. You will rise up trembling and say: I am wounded by love). Translation adapted from Wright F.A., Select Letters of St.Jerome, Loeb Classical Library 262 (Cambridge (Mass.): Harvard University Press, 1954) 67 and 109.

48 In the meantime she has but one thing to say: "Beat me, burn me, tear me in pieces. I have not done it. If you do not believe my words, the day will come when this charge will be carefully examined. I will have a judge to do me justice." Exhausted by this time, the torturer was sighing and moaning; nor could he find a place for a fresh wound. He shuddered to see the body he had torn, and his cruelty vanquished. Immediately, the governor was roused to new rage and cried: "Why does it surprise you, by-standers, that the woman prefers torture to death? It takes two people, certainly, to commit adultery; and I think it more credible that a guilty woman should deny a crime than that an innocent young man should confess one" (Rebenich, Jerome 65). 
postquam uero ad feminam uentum est et flexis in terram poplitibus super trementem ceruicem micans eleuatus est gladius et exercitatam carnifex dexteram totis uiribus concitauit, ad primum corporis tactum stetit mucro letalis et leuiter perstringens cutem rasurae modicae sanguinem aspersit. inbellem manum percussor expauit et uictam dexteram gladio marcescente miratus in secundos impetus torquet. languidus rursum in feminam mucro delabitur et, quasi ferrum ream timeret adtingere, circa ceruicem torpet innoxium (ep. 1, 7).49

At the third attempt the executioner's golden brooch falls to the ground. As the woman notices this, she alerts him to pick it up:

itaque furens et anhelus lictor paludamento in ceruicem retorto, dum totas expedit uires, fibulam, quae chlamydis mordebat oras, in humum excussit ignarusque rei ensem librat in uulnus et "en tibi," ait mulier, "ex umero aurum ruit. collige multo quaesitum labore, ne pereat" $($ ep. 1,7$){ }^{50}$

In a digression, the narrator explains this move by the woman as a sign of her composure in face of death (securitas) - an aspect that is perfectly in accordance with the way she behaved during torture - and as an act of beneficence or perhaps charity (praestabat beneficium saeuienti), although we should add the woman does not actually give anything out of her own resources:

Rogo, quae est ista securitas? inpendentem non timet mortem, laetatur percussa, carnifex pallet; oculi gladium non uidentes tantum fibulam uident et, ne parum esset, quod non formidabat interitum, praestabat beneficium saeuienti. iam igitur et tertius ictus: sacramentum frustrauerat trinitatis.

49 Then came the woman's turn. She knelt down upon the ground, and the gleaming sword was lifted over her trembling neck. The executioner summoned all his strength into his trained right arm, but the moment it touched her body the deadly sword stopped short, and, lightly grazing the skin, merely scratched it sufficiently to draw a little blood. The striker became frightened by the failure of his hand; he is amazed that his right arm has been defeated, the sword becoming powerless, and whirled it for a second stroke. Again the sword fell forceless on the woman, sinking harmlessly on her neck, as though the steel feared to touch the accused (Rebenich, Jerome 66).

5o Thereupon the enraged and panting soldier threw his cloak back over his shoulder. As he gave his full strength to the blow, he shook to the ground the brooch which clasped the edges of his garment, and not noticing this, he poised his sword for another stroke. "Look," said the woman, "a gold pin has fallen from your shoulder. Pick up what you have earned by hard labour, that you may not lose it” (Rebenich, Jerome 66). 
iam speculator exterritus et non credens ferro mucronem aptabat in iugulum, ut, qui secare non poterat, saltim premente manu corpori conderetur:o omnibus inaudita res saeculis! - ad capulum gladius reflectitur et uelut dominum suum uictus aspiciens confessus est se ferire non posse (ep. 1, 8).51

At the same time the digression is a subtle ironical comment on the executioner. A gift to one's executioner figures also in the Acta proconsularia Cypriani, where Cyprian asks to donate twenty five gold coins to his executioner. ${ }^{52}$ Cyprian's move too could be interpreted as a way to show his moral superiority (as well as his social status). However, the brooch is something the executioner acquired through hard work. This could mean that he directly or indirectly acquired it from previously condemned people ${ }^{53}$ a possible hint at this stinging undertone might have been the use of pereat - the only time the word refers to an object that is lost and not to a person who is to be slaughtered.

The narrator concludes his intermezzo by drawing theological and biblical parallels. The third blow of the sword was rendered vain by the workings of the holy Trinity; then, the martyrdom theme is restated by invoking biblical exempla:

Huc, huc mihi trium exempla puerorum, qui inter frigidos flammarum globos hymnos edidere pro fletibus, circa quorum sarabara sanctamque caesariem innoxium lusit incendium. huc beati Danihelis reuocetur historia, iuxta quem adulantibus caudis praedam suam leonum ora timuerunt. nunc Susanna nobilis fide mentes omnium subeat, quae iniquo damnata

$5^{1}$ I ask you, what is the source of such confidence? She has no fear of the death that threatens her. While she exults, when hit hard, the executioner turns pale. Her eyes do not see the sword, they only see the brooch. And as though to have no fear of death were not enough, she does an act of kindness to her cruel enemy. And now the mystery of the Trinity had rendered vain the third blow, too; the soldier was thoroughly terrified, and no longer trusting the blade put the point to her throat, with the idea that the sword which could not cut, might plunge into her body by the pressure of his hand. The sword - an amazing fact, unheard of throughout the ages - bent back to the hilt, and, as if looking at its master in its defeat, confessed its inability to strike (Rebenich, Jerome 66).

$5^{2}$ Acta Proconsularia Sancti Cypriani, § 4, ed. Musurillo 174: et cum uenisset speculator, iussit suis ut eidem speculatori aureos uiginti quinque dare. (On the executioner's arrival, he ordered his friends to give him twenty-five gold coins.)

53 The law formally prohibited the executioners from appropriating the belongings of the executed, let alone his entire property (Ulpian in Digesta, 48, 20, 6), see Mommsen Theodor, Römisches Strafrecht (Graz: Akademische Druck- und Verlagsanstalt 1899/1955) 924-925 n. 6. 
iudicio sancto spiritu puerum replente seruata est. ecce non dispar in utraque misericordia domini: illa liberata per iudicem, ne iret ad gladium, haec a iudice damnata absoluta per gladium est (ep. 1, 9).54

The woman is compared to three exempla from the book of Daniel. The three youths in the furnace (Dan. 3, 19-30), Daniel in the lions' den (Dan. 6) and Susanna (Dan. 13). The first two examples not only express the failed attempts to kill an innocent person, who is protected by God, but are well-known models of martyrdom ${ }^{55}$ as well. The lions' den furthermore evokes the role lions played in the early Christian martyrological discourse. ${ }^{56}$ Susanna is also an obvious biblical parallel. ${ }^{57}$ Although there is not a word on (false) witnesses

54 Now, now let me bring to mind the example of the three children, who, amid the cool circles of the flames, sang hymns instead of weeping, and around whose turbans and holy hair the flames played harmlessly. Now let me recall the story of the blessed Daniel, according to which the lions wagged their tails and were afraid of their prey. Let Susannah also ascend to the minds of all in the nobility of her faith, who, after she had been condemned by an unjust sentence, was saved by a youth filled with the Holy Spirit. Note that in both cases the Lord's mercy was not dissimilar; Susannah was freed by the judge that she might not die by the sword; this woman, who had been condemned by the judge, was acquitted by the sword (Rebenich, Jerome 66).

55 Already Clemens Romanus (1Clem 45: 4-7) combines Daniel in the lions' den and the three youths in the oven as examples of the persecuted and suffering innocent. Both models also appear in some 3 rd, 4th and early $5^{\text {th }}$ century acts and passions of the martyrs, so to parallel martyrdom with its Biblical precursors (lions' den: e.g. Passio Didymi \& Theodorae §8, edited by Lanéry Cécile, Analecta Bollandiana 122 (2004), 5-50: 44, 45); Passio Marcianae (Mombritius Boninus (ed.), Sanctuarium seu Vitae sanctorum. (Hildesheim, New York: Georg Olms, 1978/1910), 256-257: 256); three youths: e.g. Passio Montani \& Lucii (\$3) 214); Passio Mammarii presb. \& sociorum ( 7 , Acta SS. Iun II, 267-272: 270)). The two motifs appear together in funerary art too, as symbols of redemption and resurrection. On the use in iconography, see Schlosser, Hanspeter, Lexikon der christlichen Ikonographie. s.v. "Daniel” vol. 1 (1968) 469-473.

56 E.g. Ignatius of Antioch (in his Letter to the Romans $\S 4$ he expressed his desire that he as "God's wheat" may be "ground by the teeth of wild beasts that I may be found pure bread of Christ”); Polycarpus ( $\$ 12$, ed. Musurillo 10: the crowd requests this mode of execution), Conon ( $\$ 5$, ed. Musurillo 190: the prefect threatens to throw Conon to a lion if he refuses to honor the gods); see also Tertullian's sarcastic statim "Christianos ad leonem!" adclamatur (Apolog. 40, 1). Thecla is condemned to the beasts (lions and bears) in the Acts of Paul and Thecla (9.1). In this way she is depicted as a martyr.

57 Both in the context of false charges of adultery and of martyrdom: see Praet Danny, "Susanna, the Fathers and the Passio Sereni (внL 7595-6): Sexual Morals, Intertextuality and Early Christian Self-Definition," Zeitschrift für Antikes Christentum 143 (2011) 556-580, especially $566-567$. 
or on blackmail, the story of Susanna nonetheless resounds, ${ }^{58}$ because of the parallel subject matter (an adultery trial). The general atmosphere of the fraudulent accusations in the Bible is reflected on the events in Vercelli. He chiastically compares the way Susanna was saved by a righteous judge from the sword, with the way the septies percussa was saved from an unrighteous judge by the (failing) sword. One could argue that Jerome suggested yet another parallel: the one between Daniel as "the young man inspired by the Holy Spirit" (ep. 1, 9) who saved Susanna, and Jerome's patron Evagrius, who ultimately and definitively saved the innocent woman.

After this intermezzo (ep.1, 8-9), the text's focus shifts to the conflict between the crowd and the head of the executioners (ep. 1, 10). The people grew angry with the failing executioner and chased him away, whereupon the head of the executioners tries to avert the uproar by addressing the crowd:

"meum," inquit, "o ciues, petitis caput, me illi uicarium datis! si misericordes, si clementes estis, si uultis seruare damnatam, innocens certe perire non debeo" $\left(\right.$ ep. 1, 10). ${ }^{59}$

The readers might see the irony of these words, as the head of the executioners styles himself, exactly like the woman (cf. ep. 1, 3 cited above): an innocent victim who risks to suffer a violent death.

The people act as an anonymous mass with whom the narrator sympathizes when they sympathize with his heroine, but they are ironically despised when their sympathy shifts again to the prevailing social conventions - a convicted woman found guilty in court is to be executed. The head of the executioners addresses the crowd as citizens (o ciues ep. 1, 10), a political discourse which is perhaps in contrast with the religious discourse of the woman who consistently invokes God.

The fact that the crowd mindlessly assents to his arguments is explicitly commented upon by the narrator in terms of their changing pietas which after

$5^{8}$ Possibly the invocation of Jesus in the woman's words (ep. 1, 3 quoted above) reflects Susanna's (Dan. 13, 42-43): Deus aeterne, qui absconditorum es cognitor, qui nosti omnia antequam fiant, tu scis quoniam falsum testimonium tulerunt contra me: et ecce morior, cum nihil horum fecerim, quae isti malitiose composuerunt aduersum me. If this is a valid parallel, it proves once again the crucial importance of the woman's first direct speech in this text as that contains the rest of the story in nucleo.

59 "Is it my life you are seeking, citizens? Are you making me a substitute for her? If you are merciful, if you are clement, if you wish to save a condemned woman, surely I - an innocent man - ought not to perish" (Rebenich, Jerome 67). 
the three failed attempts led them to plead for the release of the woman and, after the plea by the head of the guards, led them to allow her execution:

quo fletu uulgi concussus est animus maestusque se per omnes torpor insinuat et mirum in modum uoluntate mutata, cum pietatis fuisset, quod ante defenderant, pietatis uisum est genus, ut paterentur occidi (ep. 1, 10). ${ }^{60}$

Unwittingly the head of the executioners highlights in his words to the crowd the central issue of the story: the unjust death of an innocent person. This aspect is stressed again by the narrator in the conclusion of the execution story - that is, the fact that she seemed to be dying, after the third attempt of a second executioner:

nouus igitur ensis, nouus percussor adponitur. stat uictima Christo tantum fauente munita. semel percussa concutitur, iterum repetita quassatur, tertio uulnerata prosternitur et - o diuinae potentiae sublimanda maiestas! quae prius fuerat quarto percussa nec laesa, ideo paululum est uisa mori, ne pro ea periret innoxius $($ ep. 1,11$) .61$

In the last line of this paragraph the "death" of the woman is presented as a selfless sacrifice to save the life of the head of the guards. This somewhat absurd twist in the story allowed Jerome to present her death, or actually her "Scheintod" - another novelistic topos ${ }^{62}-$, as the highest form of self-sacrifice, as an almost soteriological love for one's enemy. Read against the background

6o His lamentable appeal took effect upon the crowd, they were all benumbed by the influence of sorrow, and there was a strange change of will. Before, it had seemed their duty to defend the woman, now it seemed their duty in a way to allow her to be executed (Rebenich, Jerome 67).

61 Accordingly a new sword is fetched, a new executioner appointed. The victim takes her place, strengthened only with the favour of Christ. The first blow makes her quiver, beneath the second she is shaken, by the third she falls wounded to the ground. Oh, the majesty of the divine power to be extolled! She who previously had received four strokes without injury, now seems, for a moment to die, that an innocent man may not perish in her stead (Rebenich, Jerome 67).

62 "Scheintod" is a popular motif in the novels: Chariton, Callirhoe, I, 6; Xenophon of Ephesus, The Ephesian Tale of Anthia and Habrocomes, III, 6; Historia Apollonii regis Tyrii, $\S \S 25-27 ; 31-32$. It can be combined with the (deliberate, in order to deceive, or accidental) replacement of the "corpse" e.g. in Achilles Tatius, Leucippe and Clitophon, III, 15 - 17; V, 7-8; Heliodorus, Aethiopica, I, 30; II, 5; see also Petronius, Satyricon, §§ 111-112 ("the widow of Ephesus" without the Scheintod-motif). 
of a martyr's passio, ${ }^{63}$ the letter seems to highlight, not that she had to die innocently, but that she had to die innocently.

Her body is carried away by the clergy, who notice she is still breathing. They apply a ruse to save her. An old woman, who had enjoyed the local church's charity happened to have passed away recently, and her body is now put into the grave instead of the executed woman's (ep. 1, 12-13). The executioner who, as Jerome adds, is in fact the devil in disguise, cannot believe she is really dead and requires to see the body. Yet the clergy can easily ward off this request:

recens a clericis caespes ostenditur et dudum superiecta humus cum his uocibus ingeritur flagitanti: "erue scilicet ossa iam condita, infer nouum sepulchro bellum et, si hoc parum est, auibus ferisque lanianda membra discerpe; septies percussa debet aliquid morte plus perpeti" (ep. 1, 13). ${ }^{64}$

The epic undertones of the clerics' response ("declare war against a tomb," birds and wild animals devouring corpses) are slightly out of place since they are dealing with the single case of a convicted woman instead of armies, heroes and whole peoples. From a rhetorical point of view this epic overstatement is intended to dissuade the lictor. On the reader, who knows the woman is still alive, the words have a slightly humoristic effect. The clergy's reply ends on a sententia which has given the letter its later title: septies percussa debet aliquid morte plus perpeti $($ ep. 1, 13) and at the same time stresses the deliberate overstatement for the knowing reader (aliquid morte plus).

The clerics fetch a doctor to cure the woman in hiding $(e p .1,12)$ and decide to dress her as a man. They cut her hair and hide her outside Vercelli in a uillula where she lives in the company of some virgins:

63 The "love for one's enemy" finds a parallel in the fifth or sixth-century passion of Agatha (вHL 133): Agatha does not escape from prison when she has the opportunity, because of two reasons: she does not want to lose her crown of martyrdom, of course, nor does she want to expose the guards to torture (cf. Acta Sanctorum febr. I, §10: Absit a me ut ego coronam meam perdam, et eos qui custodes sunt tribulationibus tradam).

64 The clergy show him the fresh turf and the earth that a little while ago had been heaped up; they reject his demands with words as follows: "Come and dig up the bones which have just been buried! Declare war, of an unheard kind, against the tomb, and if that is not enough, scatter the limbs to be mutilated by birds and beasts! Seven times struck by the sword, she must endure something more than death" (Rebenich, Jerome 67-68, adapted; Rebenich translated infer nouum sepulchro bellum as "Declare war anew against the tomb"). 
Tali inuidia carnifice confuso clam domi mulier focilatur et, ne forte creber ad ecclesiam medici commeatus suspicionis panderet uiam, cum quibusdam uirginibus ad secretiorem uillulam secto crine transmittitur. ibi paulatim uirili habitu ueste mutata in cicatricem uulnus obducitur (ep. 1, 14). ${ }^{65}$

Thus far we have identified novelistic themes in the story, such as the "Scheintod" and (mainly) the subversion of traditional gender hierarchy. In this passage we find a further, more specific parallel with Christian "novels": gender-shifts, specifically women adopting male roles. The apocryphal Acts of Paul and Thecla are a well known example. The letter tells us in only a few words that the woman goes in hiding in a uillula, that her long hair is cut and that her women's clothes are traded in for men's clothing. This "Thecla-motif" is almost innocently inserted into the text and it is not clear what one can infer from this. Possibly Jerome implies that the woman's "afterlife" is ascetical as the result of her martyrdom. Her "victory over death," as a martyr, resulted in overcoming the earthly boundaries such as marriage, sex and gender. ${ }^{66}$ In the context of the Origenist controversy Jerome would later condemn an ascetic discourse in which women were supposed to become men. In his Letters he prefers the more sex-neutral doctrine of women transforming their bodies into an angelic status. ${ }^{67}$

However in this early letter, the Thecla-motif is very subtly present. The woman goes in hiding in a uillula inhabited by virgins, so in a type of monastic household, but she does not do this out of her own choice, and the male attire is not explicitly presented as her choice either. Jerome says nothing about her life in the uillula nor about her life after the intervention by Evagrius. So it is possible to interpret this short reference as propaganda for certain views on gender and asceticism but it is not compulsory. Those who wanted to read this

65 Such hostile words throw the executioner into confusion, and the woman is secretly revived at home. And that the frequency of the doctor's visits to the church might not give occasion for suspicion, she has her hair cut short and is sent in the company of some virgins to a secluded country house. There she changes her dress for that of a man, and gradually scars form over her wounds (Rebenich, Jerome 69).

66 See Frank Karl S., Angelikos bios: begriffsanalytische und begriffsgeschichtliche Untersuchung zum „engelgleichen Leben“ im frühen Mönchtum. (Münster: Aschendorff 1964). See also Peter Brown, Body and Society $33^{2}$ on women in the Syrian ascetic tradition who had reportedly "reduced their bodies to an "angelical" indeterminacy by long fasting. They cut off their hair and had even adopted male clothes, so as to wander freely throughout the settled world."

67 See ep. 22, 20 where the ascetic way of life is called angelorum uita. 
into the text could, while those who would oppose these views would not be scandalized since Jerome inserted the theme in such an oblique way.

As we have shown, Jerome included a few novelistic techniques and different allusions to Thecla. Yet, several elements which could have been exploited by Jerome in a novelistic or erotic sense, were not. Nothing is said about the woman's marriage except for the suggestion that it was an unhappy one. There is no explicit rejection of marriage, and the theme of a non-physical infatuation or spiritual love, as we find in the Acts of Paul and Thecla, is absent. ${ }^{68}$ Even the themes of abjuring marriage and sexuality which appear in other apocryphal acts, are absent from Jerome's letter or merely a vague possibility. We do not know whether the woman remained with the virgins or not. The final information given about this woman is that she adopted male clothing and haircut and joined virgins living in a semi-monastic community. So the whole adultery case and the martyrological torture and resistance scenes have turned this married woman, willingly or unwillingly, into a companion of virgins. It is interesting to note however that the vicissitudes of the woman totally depend on decisions and actions of men. She is accused by her husband, trialed and (nearly) executed by male officials, she is helped by the clergy and will eventually be freed through the intervention of Evagrius.

Jerome abruptly breaks off the narration and tells how his patron, Evagrius of Antioch (d. 392/3), has interceded with the emperor in order to set the woman free. In this context he refers to other aspects of Evagrius' pro Christo laborem (ep. 1, 15): he combated the Arian bishop of Milan, Auxentius (d. 373/4, bishop from 355), and helped the new bishop of Rome, Damasus (304-384, pope from 366), to overcome his enemies.

En quo me gestorum ordo protraxit! iam enim ad Euagrii nostri nomen aduenimus. cuius ego pro Christo laborem si arbitrer a me dici posse, non sapiam, si penitus tacere uelim, uoce in gaudium erumpente non possim. quis enim ualeat digno canere praeconio Auxentium Mediolanii incubantem huius excubiis sepultum paene ante quam mortuum, Romanum episcopum iam paene factionis laqueis inretitum et uicisse aduersarios et non nocuisse superatis? uerum haec ipse equidem spatiis exclusus iniquis praetereo atque aliis post $<m e>$ memoranda relinquo. praesentis tantum rei fine contentus

68 Thecla is love sick and does not react to her mother's and her fiancé's questions, to their despair, cf. Acts of Paul and Thecla, 9; this is just one example of many in the Acts of Paul and Thecla in which the erotic tension between the virgin and the apostle is thematized. Jerome knew these literary motifs, as he would subvert them in the Vita Malchi. 
sum: imperatorem industria adit, precibus fatigat, merito lenit, sollicitudine promeretur, ut redditam uitae redderet libertati $(e p .1,15) \cdot{ }^{69}$

This curious ending of the letter leaves the modern reader somewhat astonished. What has a cruel, but actually rather trivial event - an adultery trial with anonymous protagonists to do with the fight against Arianism and with high-profile Church politics involving fairly well known figures and notorious events? The story about the septies percussa takes up most of the letter whereas the Church political actions by Evagrius were mentioned only in passing. But, surprisingly, in the panegyric at the end of the letter the political affairs in which Evagrius is said to have played a key role, carry more or less the same weight as the main story of the letter. However there are some signals in the story itself as well that hint at contemporary political and religious issues. First there is the way the events are situated in Vercelli and the allusions to civil war in ep. 1, 3, as discussed above, which is possibly an allusion to the Trinitarian disputes in the second half of the fourth century. Second, the context of anti-Arianism could well have determined Jerome's choice for pausing the narration after the third blow of the sword, rendered vain by the Holy Trinity in ep. 1, 8. To Jacques Fontaine this multiple reference to triads (three blows, the Trinity, the three exempla (the first being the three youths in the furnace, then Daniel in the lions' den and Susanna)) was a sign of bad taste or the proof that Jerome was theologically still immature. ${ }^{70}$ Nonetheless the passage had potential to appeal to the readers in Northern Italy (or the Latin West generally) who aligned themselves with the Nicene party. In the final paragraph Jerome explicitly refers to Auxentius and consequently to contemporary Trinitarian disputes, although there is no link with the adultery trial. Fontaine interpreted this as a flaw in the composition, but we suggest that Jerome connected the trial with the unrelated doctrinal disputes in order to imply that his patron,

69 See now to what point the order of events has brought me! We come to the name of our friend Evagrius. If I were to suppose that I could describe his labour for Christ, I should only show my own folly; and if I decided to pass them over, I still would not be able to prevent my voice from crying out in joy. For who could fittingly proclaim that by this man's vigilance Auxentius, that nightmare of Milan, was buried even before he was dead, and the bishop of Rome, when almost entangled in the toils of faction, overcame his opponents and yet spared them in their defeat? But "this I must leave for others to relate, shut out by envious straits of time and space." I am content only to record the conclusion of the present story. Evagrius energetically seeks an audience with the emperor, wearies him with his entreaties, softens him by the service he has done him, and gains his cause through his painstaking attention. The emperor restored to liberty the woman who had been restored to life (Rebenich, Jerome 68). 
Evagrius, always chooses to support the right, that is, the orthodox and those who are unjustly accused and condemned.

Evagrius' involvement in the seemingly trivial trial in Vercelli could have been chosen by Jerome for literary reasons too. Given the "hagiographical" (martyrological and novelistic) nature of the text, Innocentius is a key figure to link Evagrius to Jerome's letter. Evagrius translated Athanasius' Vita Antonii in the early $370 .^{71} \mathrm{He}$ dedicated it to the same Innocentius who died in 374, but according to the dedication was still alive when Evagrius had finished it. He is also the recipient of Epistula prima. As Evagrius is mentioned and praised at the end, after a story in which he played no role, it seems probable that by addressing his letter to Innocentius, Jerome inserted a subtle reference to Evagrius. This way he probably wanted to impress him and other readers. Moreover, soon Jerome would write his first proper ascetic Vita. This first letter could enhance the success of his Vita Pauli as it had already established his credibility as a Christian writer.

The historical references in the letter stand in contrast to the anonymous characters in the main story. On a literary level this means that Jerome wants his readers to pay attention to yet another move between genres and conventions.

From this analysis it is clear that the Epistula prima cannot be reduced to a literary debut that betrays the clumsiness of a beginning author. Instead we must interpret Jerome's text as a literary experiment, a blend of different genres of secular and religious writing. The martyrological and novelistic literature is a dominant source of inspiration here, but none of the genres referred to or used by Jerome is unambiguously present in this letter. The woman's trial is not a martyrdom. It is a mere secular trial on adultery. The governor and the headsman are not antichristian pagans; they are merely officials who work within the secular system of justice, so there is actually no conflict between pagans and Christians. Naturally we should not forget that the adultery "case" and even the intercession by Evagrius could be historical. In spite of Jerome's martyrological interpretation of what could have happened, there is nothing intrinsically religious about the trial.

However, this text is not a plain narrative of martyrdom, neither is it a novel or ascetical propaganda or a pro-Nicene polemic, but it contains traces of each. It is thus a fusion of fiction and historicity into something we could call theological or religious sensationalist literature, Christian "Unterhaltungsliteratur", to use Herbert Kech's term, ${ }^{72}$ but with a serious ideological message.

71 Evagrius' translation in PL 73, 125-70 and a translation of Evagrius' translation in White Carolinne, Early Christian Lives. Penguin Classics. (London: Penguin 1998) 7-70.

72 See $n .35$. 